\title{
Diagnostic Test of Serum Pregnancy-Associated Plasma Protein-A Level as Biomarker for Early Diagnosis of Acute Myocardial Infarction
}

\author{
Novida Dwi Astuti, JB. Suparyatmo, Amiroh Kurniati \\ Department of Clinical Pathology, Faculty of Medicine, Sebelas Maret University/Dr. Moewardi Hospital, Surakarta, Indonesia. \\ E-mail:dr.novida@gmail.com
}

\begin{abstract}
Acute coronary syndrome is the primary cause of death from heart disease worldwide. This syndrome is caused by ruptured/eroded coronary atherosclerotic plaque, resulting in partial/total occlusion of thrombosis. It is necessary to find novel cardiac biomarkers for the identification of plaque progression before ischemic and myocardial necrosis events. Pregnancy Associated Plasma Protein-A (PAPP-A) is an atherosclerotic mediator proven to be a biomarker for plaque instability. This study aimed to determine the performance of serum PAPP-A as a biomarker for the early diagnosis of AMI. This research was an analytical observational study with a cross-sectional approach. Serum PAPP-A was measured using enzyme-linked immunosorbent assay in 82 new patients. They had ACS and were admitted to the emergency installation of Dr. Moewardi Hospital in Surakarta in August-September 2019. The subjects were grouped into the AMI group (NSTEMI and STEMI) consisting of 49(59.8\%) subjects and non-AMI (UAP) group composed of 33(40.2\%) subjects based on ACS diagnostic criteria of PERKI 2018. Receiver Operator Characteristic (ROC) curve analysis showed that PAPP-A was a good discriminator between AMI and non-AMI patients. The area under the curve was $0.968,95 \% \mathrm{CI}(0.932-1.004)$, with a sensitivity of $91.8 \%$ and specificity of $90.9 \%$ ( $p<0.05$ ). The cut-off value from the ROC curve was $2,526 \mathrm{ng} / \mathrm{mL}$. Serum PAPP-A level has excellent performance as a biomarker for early diagnosis of AMI. It can also function as a screening instrument for the identification of UAP cases developing into AMI.
\end{abstract}

Keyword: PAPP-A, acute coronary syndrome, acute myocardial infarction

\section{INTRODUCTION}

Acute Coronary Syndrome (ACS) is a group of clinical manifestations due to the disruption of the coronary arteries caused by rupture/erosion of the coronary atherosclerotic plaque. The ruptured/eroded plaque subsequently results in partial or total thrombosis occlusion. This syndrome consists of Acute Myocardial Infarction (AMI) with or without ST-segment elevation and Unstable Angina Pectoris (UAP). ${ }^{1-3}$

Acute myocardial infarction is the incidence of myocardial necrosis caused by the unstable ischemic syndrome. ${ }^{4}$ The diagnosis of AMI is based on clinical symptoms such as chest pain, a history of $\mathrm{CHD}$, a typical electrocardiographic (ECG) image, both STEMI and NSTEMI, and increased biomarkers of myocardial necrosis. ${ }^{2,3}$

Unstable angina pectoris is a spectrum of ACS that involves an imbalance between available supply and the oxygen demand for the myocardium. Complaints of chest pain in UAP arise at a resting state or mild activity, whereas stable angina symptoms appear during heavy activity and disappear with rest. A distinguishing feature between UAP and AMI is the absence of an increase in myocardial necrosis biomarkers, such as troponin, which represents myocardial damage. ${ }^{5}$

Currently available cardiac marker parameters include mass Creatin Kinase-MB (CK-MB), troponin $\mathrm{I} / \mathrm{T}$, and myoglobin. Creatin kinase mass and troponin I/T are biomarkers of myocardial necrosis that are widely used, especially in the diagnosis of myocardial infarction. Troponin I/T is currently the gold standard for establishing AMI diagnoses due to its higher sensitivity and specificity compared to CK-MB mass. ${ }^{3,6}$

Considering the increase in myocardial necrosis biomarkers of CK-MB mass and troponin I/T within at least 4-6 hours, depending on the extent of myocardial necrosis, this can cause delay/error in diagnosis and treatment of patients with ACS. The incidence of AMI (NSTEMI), which is not accompanied by an increase in myocardial necrosis biomarkers and many UAPs are not recognized as ACS, this results in a misdiagnosis, that AMI treatment strategies cannot be immediately established. ${ }^{3}$ 
Measurement of myocardial necrosis biomarkers plays an essential role in establishing the diagnosis and risk stratification of patients with suspected AMI. Myocardial necrosis biomarkers that have good sensitivity and specificity with faster emergence time than CK-MB mass and troponin I/T is needed. The biomarker is used for early enforcement of AMI diagnosis, identifying the development and activity of atherosclerosis plaque before the occurrence of myocardial necrosis, especially for monitoring/screening UAP cases developing to $\mathrm{AMI}^{3}$

Pregnancy-associated plasma protein- $A$ is a zinc-binding metalloproteinase, which has the potential for proatherosclerosis and has been shown to be a specific activator of Insulin-Like Growth Factor I (IGF-I), a mediator of atherosclerosis, produced by Vascular Smooth Muscle Cells (VSMC), Endhotellial Cells (EC), fibroblasts and macrophages that are activated by the presence of proinflammatory cytokines, especially interleukin- $1 \beta$ (IL-1 $\beta$ ) and tumor necrosis factors- $\alpha$ (TNF- $\alpha)^{7.8}$

Previous studies have shown that PAPP-A is abundantly expressed in eroded and ruptured plaque, but only minimally expressed in stable plaque, and released into the blood circulation immediately after the vulnerable plaque/unstable plaque has ruptured or eroded. . $7,9,10^{2}$

\section{METHODS}

This study was an observational analytic study with a cross-sectional approach to determine the performance of serum PAPP-A levels as biomarkers for early diagnosis of AMI. The study involved 82 new patients in the emergency room at the Dr. Moewardi Hospital, Surakarta, who were diagnosed with new ACS (UAP, NSTEMI, and STEMI) by clinicians according to PERKI 2018 during August to September 2019.

The inclusion criteria of this study were new ACS patients, aged $\geq 18$ years, willing to participate in the research and sign the consent form. Exclusion criteria were patients with a history of heart failure, pregnancy at the time of sampling, post-abortion/postpartum at least one month earlier, malignancy, impaired renal function, impaired liver function, stroke, history of major surgery or trauma of at least three months previously (obtained from the history and medical records), and unqualified sample conditions such as hemolysis, jaundice and lipemic.

Serum PAPP-A measurement was performed using serum samples, human PAPP-A sandwich enzyme-ELISA quantikine reagent kit, and Rayto
RT-2100C (microplate reader) at a wavelength of $450 \mathrm{~nm}$. High sensitive troponin I (hs-TnI) and mass CKMB levels were measured with Vidas Biomerieux. Random glucose level, total cholesterol, HDL cholesterol, LDL cholesterol, triglycerides, and hs-CRP levels were measured by Architect 14000 Biorad.

Laboratory tests were preceded by a within-day precision test to ensure the quality of the measurement results. Data on the basic characteristics of research subjects and research variables were expressed in $n(\%)$, mean $\pm S D$, or median $\left(25^{\text {th }}-75^{\text {th }}\right.$ percentile).

Data were analyzed using descriptive analysis. The Kolmogorov-Smirnov statistical test was used to determine the pattern of data distribution because this study involved 82 research subjects. Normally distributed data were stated as mean $\pm S D$, whereas abnormally distributed data were stated as medians $\left(25^{\text {th }}-75^{\text {th }}\right.$ percentile).

This study performed different tests. Chi-Square test was used on data with a nominal scale such as gender, family history of heart disease, history of DM, history of hypertension, history of dyslipidemia, and history of smoking.

Normalization test in the AMI group (NSTEMI, STEMI) and non-AMI (UAP) were performed with the Shapiro-Wilk test because there were 49 subjects in the AMI group (NSTEMI, STEMI) and 33 subjects in the non-AMI group (UAP). The difference test of an independent T-test was used for normally distributed data. In contrast, the Mann-Whitney test was used for abnormally distributed data to the laboratory parameters in the AMI group (NSTEMI and STEMI) and non-AMI (UAP). Groups were determined based on ACS diagnostic criteria, according to PERKI 2018.

Cut-off parameters of serum PAPP-A were obtained from the ROC and AUC curves before the diagnostic test was performed with a $2 \times 2$ table to measure sensitivity, specificity, PPV, NPV, PLR, and NLR for serum PAPP-A levels against diagnostic criteria of ACS patients according to PERKI 2018. Data were statistically analyzed using the SPSS version 16.0 program. The result was significant, with $\mathrm{p}<0.05$ with a $95 \% \mathrm{CI}$.

This study was approved by Dr. Moewardi Hospital, Surakarta Research Ethics Committee in Surakarta, with an ethical clearance letter dated August 27, 2019, number 1035/VII/HREC/2019.

\section{RESULTS AND DISCUSSION}

The study involved 82 patients diagnosed with ACS (UAP, NSTEMI, and STEMI) admitted to the 
Intensive Care Unit of Dr. Moewardi Hospital in Surakarta in August-September 2019 who met the inclusion and exclusion criteria and divided into two groups: AMI and non-AMI (UAP), characteristics of research subjects can be seen in Table 1 .

Based on the characteristics of the research subjects on Table 1 , there were no significant differences $(p>0.05)$ on variables of gender, age, family history of cardiac disease, history of DM, history of hypertension, history of dyslipidemia, history of smoking, serum total cholesterol levels, serum triglyceride levels, serum HDL cholesterol levels, serum LDL cholesterol levels, the onset of chest pain and BMI between AMI and non-AMI (UAP) patients.

Random blood glucose levels in AMI and non-AMI (UAP) patients showed a significantly different median $(p<0.05)$. AMI patients showed a higher median of the blood glucose level of 149 (125,5-220) $\mathrm{mg} / \mathrm{dL}$ compared to that of non-AMI patients of 131 $(106,5-187,5) \mathrm{mg} / \mathrm{dL}$. The difference in median blood glucose levels in the two groups was influenced by glucose control in subjects with type $2 \mathrm{DM}^{11-13}$

There was a significant difference $(p<0.05)$ in serum hs-CRP levels between AMI patients with a median value of $2.46(1.23-3.8) \mathrm{mg} / \mathrm{dL}$ and non-AMI

Table 1. Characteristics of research subjects

\begin{tabular}{|c|c|c|c|c|}
\hline $\begin{array}{c}\text { Variable } \\
\text { (measurement unit) }\end{array}$ & $\begin{array}{c}\text { Total } \\
\mathrm{N}=\mathbf{8 2 ( 1 0 0 \% )}\end{array}$ & $\begin{array}{c}\text { AMI } \\
n=49(59.8 \%)\end{array}$ & $\begin{array}{c}\text { Non-AMI } \\
\mathrm{n}=33(40.2 \%)\end{array}$ & $\mathbf{p}$ \\
\hline Gender (\%) ${ }^{\mathrm{a}}$ & & & & 0.275 \\
\hline Male & 60 (73.2\%) & 38 (77.6\%) & 22 (66.7\%) & \\
\hline Female & $22(26.8 \%)$ & $11(22.4 \%)$ & $11(33.3 \%)$ & \\
\hline Age (years old) ${ }^{b}$ & $58.37 \pm 9.6$ & $58.33 \pm 10.09$ & $58.42+8.98$ & 0.946 \\
\hline \multicolumn{5}{|l|}{ Medical history } \\
\hline Cardiac disease $(\%)^{a}$ & 31 (37.8\%) & 18 (36.7\%) & 12 (36.4\%) & 0.973 \\
\hline $\mathrm{DM}(\%)^{\mathrm{a}}$ & $31(37.8 \%)$ & 20 (40.8\%) & $11(33.3 \%)$ & 0.493 \\
\hline Hipertension (\%) ${ }^{\mathrm{a}}$ & $55(67.1 \%)$ & $31(63.3 \%)$ & $25(75.8 \%)$ & 0.233 \\
\hline Dyslipidemia (\%) ${ }^{\mathrm{a}}$ & $46(56.1 \%)$ & $26(53.1 \%)$ & $21(63.6 \%)$ & 0.342 \\
\hline Smoking (\%) ${ }^{a}$ & 50 (61\%) & $30(61.2 \%)$ & 19 (57.6\%) & 0.471 \\
\hline $\begin{array}{l}\text { Random blood glucose } \\
\text { level }(\mathrm{mg} / \mathrm{dL})^{c}\end{array}$ & $138(115,5-200,5)$ & $\begin{array}{c}149 \\
(125,5-220)\end{array}$ & $\begin{array}{c}131 \\
(106,5-187,5)\end{array}$ & $0.043^{*}$ \\
\hline $\begin{array}{l}\text { Serum total cholesterol } \\
(\mathrm{mg} / \mathrm{dL})^{\mathrm{b}}\end{array}$ & $182,09 \pm 53.61$ & $176.57 \pm 49.17$ & $190,27 \pm 59.43$ & 0.259 \\
\hline Serum triglyceride $(\mathrm{mg} / \mathrm{dL})^{c}$ & $\begin{array}{c}121,5 \\
(89.75-169,25)\end{array}$ & $\begin{array}{c}121 \\
(88.50-162)\end{array}$ & $\begin{array}{c}128 \\
(92.00-175)\end{array}$ & 0.702 \\
\hline Serum HDL $(\mathrm{mg} / \mathrm{dL})^{c}$ & $\begin{array}{c}40 \\
(34-48)\end{array}$ & $\begin{array}{c}40 \\
(34-50)\end{array}$ & $\begin{array}{c}41 \\
(35-46.5)\end{array}$ & 0.698 \\
\hline Serum LDL $(\mathrm{mg} / \mathrm{dL})^{c}$ & $126,79 \pm 47.96$ & $\begin{array}{c}118 \\
(98.5-145.5)\end{array}$ & $\begin{array}{c}130 \\
(93.50-168,5)\end{array}$ & 0.321 \\
\hline Serum hs-CRP (mg/dL) ${ }^{c}$ & $\begin{array}{c}1.02 \\
(0.57-2.89)\end{array}$ & $\begin{array}{c}2.46 \\
(1.23-3.8)\end{array}$ & $\begin{array}{c}0.55 \\
(0.36-0.87)\end{array}$ & $0.0001^{*}$ \\
\hline hs-TnI (ng/L) & $\begin{array}{c}167.1 \\
(11.73-1639,45)\end{array}$ & $\begin{array}{c}787.4 \\
(184,4-4719,1)\end{array}$ & $\begin{array}{c}4.8 \\
(1.7525 .25)\end{array}$ & $0.0001^{*}$ \\
\hline $\begin{array}{l}\text { CK-MB mass } \\
(\mathrm{ng} / \mathrm{L})\end{array}$ & $\begin{array}{c}4.69 \\
(1.91-12.39)\end{array}$ & $\begin{array}{c}8.25 \\
(4.86-39.1)\end{array}$ & $\begin{array}{c}1.82 \\
(0.94-2.69)\end{array}$ & $0.0001^{*}$ \\
\hline Onset of chest pain (hour) ${ }^{c}$ & $\begin{array}{c}5.5 \\
(3.38-24.47)\end{array}$ & $\begin{array}{c}6 \\
(3.00-7)\end{array}$ & $\begin{array}{c}5 \\
(3.75-8)\end{array}$ & 0.669 \\
\hline $\begin{array}{l}\text { Body mass index } \\
\left(\mathrm{kg} / \mathrm{m}^{2}\right)^{\mathrm{b}}\end{array}$ & $\begin{array}{c}22.11 \\
(20.88-24.47)\end{array}$ & $23.03 \pm 2.84$ & $22.25 \pm 2.17$ & 0.189 \\
\hline
\end{tabular}

Description:

DM = Diabetes Melitus; HDL = High Density Lipoprotein; LDL = Low Density Lipoprotein; hs-CRP = High Sensitivity C-Reactive Protein; hs-TnI = High Sensitivity-Troponin I; CK-MB Mass = Creatin Kinase-MB Mass

a: nominal data, presented in (\%), Difference test of Chi-Square test was used, $p<0.05$ was significant

b: normally distributed data, presented as mean $\pm S D$, difference test with independent T-test was used, $p<0.05$ was significant c: abnormally distributed data, presented as median $\left(25^{\text {th }}-75^{\text {th }}\right.$ percentile), difference test of Mann-Whitney test was used, $p<0.05$ was significant; *: $p<0.05$ was significant 
(UAP) 0.55 (0.36-0.87) $\mathrm{mg} / \mathrm{dL}$, suggesting a higher median value of hs-CRP levels in AMI patients compared to that of non-AMI (UAP) patients. This finding supports the theory that ACS is a disease that occurs due to an ongoing inflammatory process. Acute myocardial infarction patients develop acute and severe inflammatory processes, as evidenced by an increase in inflammatory markers. Highly sensitive C-reactive protein is an acute-phase reactant, and its increased levels represent the ongoing acute inflammatory process. The reference range for cardiovascular risk is < $0.1 \mathrm{mg} / \mathrm{dL}$ for low risk; 0.1-0.3 $\mathrm{mg} / \mathrm{dL}$ for intermediate-risk; $0.3-1 \mathrm{mg} / \mathrm{dL}$ for high risk, and > $1 \mathrm{mg} / \mathrm{dL}$ for unspecific elevation. ${ }^{11,13}$

There was a significant difference in hs-TnI levels $(p<0.05)$ among AMI patients and higher median in AMI patients [median $\left(25^{\text {th }}-75^{\text {th }}\right.$ percentile) 787,40 $(184,40-4719,10) \mathrm{ng} / \mathrm{L}]$ compared to non-AMI patients (UAP) [median $\left(25^{\text {th }}-75^{\text {th }}\right.$ percentile) 4.80 (1.75-25.25) ng/L]. There was a significant difference of mass CK-MB levels in AMI patients with $p=0.0001$ $(p<0.05)$ and higher median in AMI patients [median $\left(25^{\text {th }}\right.$ percentile $\left.75^{\text {th }}\right) 8.25$ (4.86-39.1) $\left.\mathrm{ng} / \mathrm{L}\right]$ compared to non-AMI (UAP) patients [median $\left(25^{\text {th }}-75^{\text {th }}\right.$ percentile) $1.82(0.94-2.69) \mathrm{ng} / \mathrm{L}]$. The study results were following the definitions and diagnostic criteria of ACS, such as increased mass hs-TnI and CK-MB levels in AMI patients (STEMI and NSTEMI) biomarkers of myocardial necrosis. The median of hs-TnI and CK-MB mass of non-AMI (UAP) patients was much lower than the group of AMI patients, that the levels did not exceed the ULs of hs-TnI and CK-MB. ${ }^{3}$

According to characteristics of research variables in Tabel 2, the median value of serum PAPP-A of all research subjects was 12.61 (1.03-32.92) ng/mL, with details as follows: median value of 32.11 (22.05-36.44) ng/mL was found in AMI (NSTEMI, STEMI) patients and $1.01(0.95-1.07) \mathrm{ng} / \mathrm{mL}$ was found in non-AMI (UAP) patients. Results of Mann-Whitney test showed a very significant difference $(p<0.000)$ of serum PAPP-A levels between AMI (NSTEMI, STEMI) patients and non-AMI patients, showing a significantly higher serum PAPP-A levels in AMI patients compared to non-AMI (UAP) patients.
The results of this study support previous studies that analyzed serum PAPP-A levels in ACS. ${ }^{14}$ Serum PAPP-A levels in AMI patients (NSTEMI and STEMI) were found to be increased, although elevated levels of hs-Troponin I and CK-MB mass were not found in some AMI patients, showing a similar result to the previous study by Bayes et al., and Wang et al., which suggested that PAPP-A is abundantly expressed in vulnerable/eroded/ruptured plaque, but only minimally shown in unstable plaque, PAPP-A is also released into the blood circulation immediately after the vulnerable plaque/unstable plaque is ruptured or eroded, when an increase in levels of hs-TnI and CK-MB mass released by myocardial necrosis has not been detected. ${ }^{2,7}$

In non-AMI (UAP) study subjects, the median value of serum PAPP-A levels were obtained as follows: [median $\left(25^{\text {th }}\right.$ percentile 75$)$, median 1.01 (0.95-1.07) ng/mL], without any finding of increased hs-TnI and CK-MB mass levels, suggesting that PAPP-A levels can be used as biomarkers for monitoring the progression of UAP to develop into AMI before changes in the typical ECG image and an increase in myocardial necrosis biomarkers (hs-TnI and CK-MB mass) are detected. The mean value of PAPP-A levels of $29.22 \pm 11.88$ and $1.94 \pm 2.61 \mathrm{ng} / \mathrm{mL}$ were found in subjects with and without elevated levels of hs-TnI (T0 $\geq 100 \mathrm{ng} / \mathrm{L}$ ), respectively. Besides, mean values of PAPP-A levels of $26.6 \pm 13.61$ and $4.78 \pm 9.41 \mathrm{ng} / \mathrm{mL}$ were found in subjects with increased ( $\geq 4.3 \mathrm{ng} / \mathrm{L}$ ) and without increased levels of CKMB mass, respectively.

Serum PAPP-A levels have more advantages than other myocardial necrosis biomarkers (hs-TnI and CK-MB mass) to diagnose AMI, that it can be detected in serum levels before elevated levels of hs-TnI and CK-MB mass are detected. However, it has a weakness that it is not as specific as a cardiac biomarker, PAPP-A has been identified in tissues other than the placenta produced by VSMC, EC, fibroblasts, and macrophages that are activated by proinflammatory cytokines, especially interleukin-1 $\beta$ (IL-1 $\beta$ ) and tumor necrosis factors- $\alpha$ (TNF- $\alpha)$, ${ }^{6,715,16}$

The cut-off was determined using the ROC curve (Figure 1). The ROC curve showed that the cut-off for

Table 2. Characteristics of research variables

\begin{tabular}{lcccc}
\hline Variable & $\begin{array}{c}\text { Total } \\
(\mathbf{n = 8 2})\end{array}$ & $\begin{array}{c}\text { AMI } \\
(\mathbf{n = 4 9 )}\end{array}$ & $\begin{array}{c}\text { Non-AMI } \\
(\mathbf{n = 3 3 )}\end{array}$ & $\mathbf{p}$ \\
\hline $\begin{array}{l}\text { PAPP-A levels } \\
(\mathrm{ng} / \mathrm{mL})\end{array}$ & $\begin{array}{c}12.61 \\
(1.03-32.92)\end{array}$ & $\begin{array}{c}32.11 \\
(22.05-36.44)\end{array}$ & $\begin{array}{c}1.01 \\
(0.95-1.07)\end{array}$ & $0.0001^{*}$ \\
\hline
\end{tabular}

Description:

PAPP-A = Pregnancy-Associated Plasma Protein-A; $\mathrm{mg} / \mathrm{dL}=$ miligram per desilitre; $\mathrm{ng} / \mathrm{L}=$ nanogram per litre. Data were presented as median $\left(25^{\text {th }}-75^{\text {th }}\right.$ percentile), difference test of Mann-Whitney test was used, $p<0.05$ was significant 
serum PAPPA levels was $2,526 \mathrm{ng} / \mathrm{mL}$ with an AUC value of 0.968 and a $95 \%$ confidence interval (0.932-1.004).

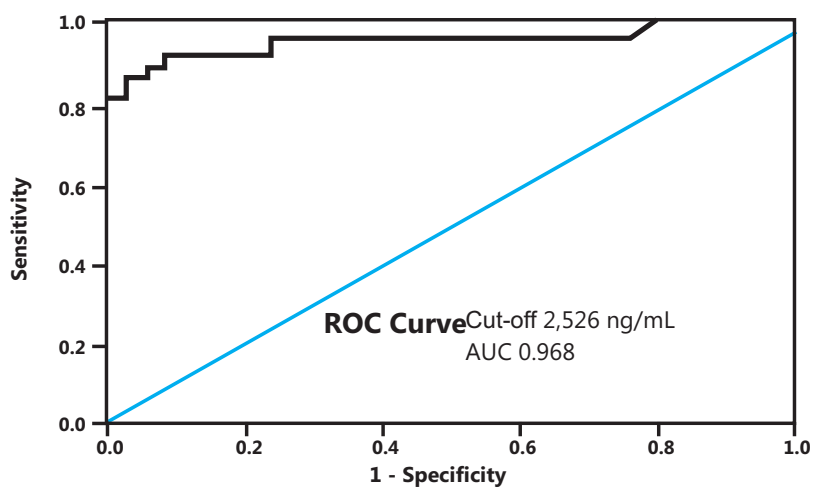

Figure 1. ROC curve of serum PAPP-A levels in AMI incidence

Results of diagnostic tests with a cut-off of 2,526 $\mathrm{ng} / \mathrm{mL}$ for serum PAPP-A levels are shown in Table 3. Serum PAPP-A levels $\geq 2,526 \mathrm{ng} / \mathrm{mL}$ were identified as positive AMI, and levels $<2,526 \mathrm{ng} / \mathrm{mL}$ were identified as negative (non-AMI).

Table $2 \times 2$ of the diagnostic test shows that 48 patients (58.54\%) out of a total of 82 subjects had serum PAPPA levels $\geq 2,526 \mathrm{ng} / \mathrm{mL}$, consisting of 45 patients (54.88\%) positively diagnosed with AMI and three patients (3.66\%) diagnosed as non-AMI (UAP). From a total of 34 patients (41.46\%) with serum PAPP-A levels $<2,526 \mathrm{ng} / \mathrm{mL}$, it was found that four patients (4.88\%) were positively diagnosed with AMI and 30 patients (36.58\%) were negative AMI and diagnosed non-AMI (UAP) instead (Table 3).

From the results of diagnostic tests, the performance of serum PAPP-A levels as biomarkers for early diagnosis of AMI was as follows: sensitivity of $91.8 \%$; specificity of $90.9 \%$; PPV of $93.8 \%$; NPV of $88.2 \%$; PLR of 10.1; and NLR of 0.1 with an AUC value of 0.968 CI $95 \%$ (0.932-1.004).

The diagnostic test results above show that serum PAPP-A levels have excellent performance as an early
AMI biomarker because they have outstanding AUC values (> 0.9-1). The sensitivity and specificity of serum PAPP-A > 90\% indicate that serum PAPP-A can function as a screening instruments and its use as an early diagnostic instrument. The higher sensitivity values compared to specificity enable serum PAPP-A levels to be a screening biomarker, which can identify AMI cases and screen UAP patients who develop into myocardial infarction (NSTEMI or STEMI). The diagnostic value of a laboratory test is considered good if the PLR value is almost ten, and the NLR is nearly 0 . Serum PAPP-A levels in this study has an excellent diagnostic value for early diagnosis of AMI because it has a PLR value of 10.1 and an NLR value of $0.1^{17,18}$

The characteristics of the subjects of this study also support the research by Wang et al., which presented a table of risk factors related to ACS in the study subjects. It was mentioned that there was no significant difference in age, family history of CHD, hypertension, hyperlipidemia, DM, smoking, sedentary lifestyle, and BMI between the ACS groups and the healthy control group. The study also found significant differences in serum glucose levels, total cholesterol, HDL cholesterol, LDL cholesterol, triglycerides, and diastolic blood pressure between ACS patients and healthy control groups, with the higher mean value of the parameters in ACS patients compared with healthy patients. ${ }^{2}$

This study also supports research by Gururajan et al. The characteristics table of the study subjects showed that there was no significant difference in mean values of serum glucose, total cholesterol, HDL cholesterol, LDL cholesterol, and triglycerides between the STEMI, NSTEMI, and UAP groups. However, there was a significant difference if compared to the healthy control and Non-Cardiac Chest Pain (NCCP). ${ }^{10}$

The results of this study indicated that serum PAPP-A levels in AMI (NSTEMI and STEMI) patients were much higher than in non-AMI (UAP) patients,

Table 3. Table $2 \times 2$ of the diagnostic test of PAPP-A to ACS diagnostic criteria

\begin{tabular}{cccc}
\hline & \multicolumn{2}{c}{ Diagnostic Criteria (gold standard) } & \\
\cline { 2 - 3 } Serum PAPP-A & $\mathbf{A M I}$ & $\mathbf{N}$ & \multirow{2}{*}{ Total } \\
$(\mathbf{n g} / \mathbf{m L})$ & $\mathbf{n}(\%)$ & $\mathbf{n}$ (\%) & \\
& Positive & Negative & \\
\hline Positive $(\geq 2,526)$ & $45(54.88 \%)$ & $3(3.66 \%)$ & $48(58.54 \%)$ \\
Negative $(<2,526)$ & $4(4.88 \%)$ & $30(36.58 \%)$ & $34(41.46 \%)$ \\
& $49(59.76 \%)$ & $33(40.24 \%)$ & $82(100 \%)$ \\
\hline
\end{tabular}

Note: PAPP-A=Pregnancy-Associated Plasma Protein-A, AMI=Acute Myocardial Infarction 
despite no increased hs-TnI levels were found in some AMI patients, showing a similar result to the research by Bayes et al. ${ }^{7}$

The study by Heeschen et al. and Iversen et al. showed that there was no significant difference in mean serum PAPP-A levels between NSTEMI and UAP patients. Still, there was a significant difference in STEMI patients compared to NSTEMI patients and UAP. Those findings were contradictory with the results in this that serum PAPP-A levels in AMI (NSTEMI and STEMI) were much higher than serum PAPP-A levels in non-AMI (UAP) patients. ${ }^{10}$

\section{CONCLUSIONS AND SUGGESTIONS}

Measurement of serum PAPP-A levels at a cut-off of $2,526 \mathrm{ng} / \mathrm{mL}$ has an excellent diagnostic test performance as a biomarker for early diagnosis of AMI. It can also function as a screening instruments to identify UAP cases developing into AMI (NSTEMI and STEMI), with a sensitivity of $91.8 \%$; specificity of 90.9\%; PPV of $93.8 \%$; NPV of $88.2 \%$; PLR of 10.1 ; NLR of 0.1 with an AUC value of 0.968 and CI $95 \%$ (0.932 - 1.004).

Further research with prospective cohort design was needed by involving angina pectoris patients diagnosed with UAP as research subjects and additional subjects as healthy control. They performed a diagnostic test of serum PAPP-A levels by comparison and combination with other cardiac biomarkers such as myocardial necrosis and inflammation.

\section{REFERENCES}

1. Papanastasiou CA, Kokkinidis DG, Oikonomou EK, Mantziaris VG, Foley $\mathrm{T}$, et al. Pregnancy-associated plasma protein-A as a prognostic biomarker of all-cause mortality and cardiovascular events in patients presenting with chest pain: A systematic review. Biomarkers, 2017; 1-9.

2. Wang G, Wang S, Sun L, Chai H, Li J, Zhang G. Pregnancy-associated plasma protein-A and copeptin as markers in the early diagnosis of the acute coronary syndrome. Int J Clin Exp Med, 2016; 9(6): 12073-12078.

3. Perhimpunan Dokter Spesialis Kardiovaskular Indonesia. Pedoman tata laksana sindrom koroner akut. Edisi IV., Jakarta, Centra Comunication, 2018; 1-94.

4. Anderson JL, Morrow DA. Acute myocardial infarction. New England Journal of Medicine, 2017; 376: 2053-2064.
5. Cannon CP, Braundwald E. Non-ST-segment elevation acute coronary syndrome (Non-ST-segment elevation myocardial infarction and unstable angina). In Kasper DL, Hauser SL, Jameson JL, Fauci AS, Longo DL and Loscalzo J. Harrison's principles of internal medicine, $19^{\text {th }}$ Ed., New South Wales, McGraw Hill, 2015; 1593-1598.

6. Gilardi E, Iacomini P, Marsiliani D, De Marco G, Covino $\mathrm{M}$. Biomarkers in the prediction and management of acute coronary syndromes: Current perspectives. Dove Press Journal, 2014; 4(5): 21-31.

7. Bayes-Genis A, Conover CA, Overgaard MT, Bailey KR, Christiansen $\mathrm{M}$, et al. Pregnancy-associated plasma protein-A as a marker of acute coronary syndromes. $\mathrm{N}$ Engl J Med, 2001; 345: 1022-1029.

8. Wittfooth S. Free PAPP-A: A novel marker in acute coronary syndrome patients. Turku, Finland, University of Turku, 2009; 29-33.

9. Iversen KK, Teisner AS, Schoos M, Teisner B, Nielsen $H_{\text {, }}$ et al. Usefulness of pregnancy-associated plasma protein-A in patients with acute coronary syndrome. Am J Cardiol, 2009; 104:1465-1471.

10. Gururajan $P$, Gurumurthy $P$, Nayar $P$, Nagaswara Rao GS, Babu $S$, et al. Pregnancy-associated plasma protein-A (PAPP-A) as an early marker for the diagnosis of acute coronary syndrome. Indian Heart Journal, 2012; 6402: 141-145.

11. Plutzky J, Libby P. Pathophysiology of atherosclerotic heart disease. In Tonkin A. Atherosclerosis and Heart Disease. Australia, Martin Dunitz, 2003; 1-12.

12. Pasterkamp G, Den Ruijter HM, Libby P. Temporal shifts in clinical presentation and underlying mechanisms of atherosclerotic disease. Nature Review Cardiology, 2016; 1-9

13. Crea F, Libby P. Acute coronary syndromes the way forward from mechanisms to precision treatment. Circulation, 2017; 136: 1155-1166.

14. Jespersen $C H B$, Vestergaad $K R$, Schou $M$, Teisner $B$, Goetze JP, Iversen K. Pregnancy-associated plasma protein-A and the vulnerable plaque. Biomark Med, 2014; 8(8): 1033-1047.

15. Conover CA, Harrington SC, Bale LK, Oxvig C. Surface association of pregnancy-associated plasma protein-A accounts for its colocalization with activated macrophages. Am J Physiol Heart Circ Physiol, 2008; 292: 994-1000.

16. Loncar G, Haehling SV. Elevated PAPP-A sets alarm bells ringing in patients with cardiac chest pain. Expert Review of Cardiovascular Therapy Taylor \& Francis, 2013; 12(1): 5-8.

17. Dahlan S. Besar sampel dan cara pengambilan sampel dalam penelitian kesehatan. Ed 2., Jakarta, Salemba Medika, 2009; 79-105.

18. Pusponegoro HD, Wirya IGW, Pudjiadi AH, Bisanto J, Zulkarnain SZ. Uji diagnostik. Dalam: Sastroasmoro S dan Ismed S. Dasar-dasar metodologi penelitian klinis. Ed 4., Jakarta, Sagung Seto, 2011; 219-243. 